www.jmscr.igmpublication.org

Impact Factor 5.244

Index Copernicus Value: 83.27

ISSN (e)-2347-176x ISSN (p) 2455-0450

crossref DOI: _http://dx.doi.org/10.18535/jmscr/v4i10.14

Journal Of Medical Science And Clinical Research

\title{
Epidemiology of Stroke Associate with Diabetes Mellitus
}

\author{
Authors \\ Jaseera Banu. $\mathbf{K}^{\mathbf{1}}$, Naufal Rizwan.T.A ${ }^{2 *}$ \\ ${ }^{1}$ Bachelor of Dental Surgery, Saveetha Dental College, Saveetha University, Chennai \\ ${ }^{2}$ Professor and Head, Dept of General Medicine, Saveetha Medical College and Hospital, Saveetha \\ University, Chennai \\ Corresponding Author \\ Naufal Rizwan.T.A
}

\section{ABSTRACT}

Stroke also known as cerebrovascular accident or cerebrovascular insult is when poor blood flow to the brain result in brain death. The 1990 Global Burden of Disease (GBD) study provided the first global estimate on the burden of 135 diseases, and cerebrovascular diseases ranked as the second leading cause of death after ischemic heart disease. During the past decade the quantity of especially routine mortality data due to cerebrovascular disease has been increased, and is now covering approximately one-third of the world's population. Data on causes of death from the 1990s have shown that cerebrovascular diseases remain a leading cause of death. In 2001 it was estimated that cerebrovascular diseases (stroke) accounted for 5.5 million deaths world-wide, equivalent to $9.6 \%$ of all deaths. Two-thirds of these deaths occurred in people living in developing countries and $40 \%$ of the subjects were aged less than 70 years.

KEYWORDS: Cerebrovascular accident, blood flow, mortality rate, age.

\section{INTRODUCTION}

The World Health Organisation (WHO) definetion of stroke is: "rapidly developing clinical signs of focal (or global) disturbance of cerebral function, with symptoms lasting 24 hours or longer or leading to death, with no apparent cause other than of vascular origin ${ }^{(1)}$. The epidemiological studies have indicated that hypertension and type 2 diabetes are commonly associated conditions, and their concordance is increased in populations ${ }^{(2)}$. While diabetes is a well known risk factor for stroke, the magnitude of risk varies, and the impact of diabetes on stroke incidence rates is not known ${ }^{(3)}$. The prevalence of diabetes increases with age in all race/ethnicity groups ${ }^{(4)}$. Specific and nonspecific risk factors of stroke in the diabetic population include previous cerebrovascular disorders, arterial hypertension, central obesity, smoking, dyslipidemia, hyperglycaemia, diabetes duration, diabetic complications, and insulin resistance/hyperinsulinemia ${ }^{(5,6)}$.

\section{TYPES}

On the basis of pathogenesis it may be either ischemic or haemorrhagic disturbances in cerebral blood flow.

\section{ISCHEMIC STROKE}

It may be due to thrombotic cerebral infarction (atherosclerotic obstruction) embolic cerebral 
infarction (embolism of a clot) and lacunar cerebral infarction (small deep infarcts).several other causes of cerebral infarction are also present.

\section{HEMORRHAGIC STROKE}

Spontaneous intra-cerebral hemorrhages are mainly due to arteriolar hypertensive disease. Cortical amyloid angiopathy (a consequence of hypertension) is a cause of cortical haemorrhages especially occurring in elderly people.

\section{SUBARACHNOID HAEMORRHAGE}

This group of strokes is mainly due to the rupture of aneurysms at the bifurcations of large arteries at the inferior surface of the brain ${ }^{(7)}$.

\section{DISTRIBUTION OF STROKE}

In Caucasian population study the incidence rate ratios for different main types of stroke, for ischemic stroke; the ratio was 1.55 , for intracerebral haemorrhage 1.60, for SAH 0.84 and for stroke of undetermined cause $1.08^{(8)}$.

\section{RISK FACTORS}

Several studies have demonstrated that high blood pressure is an independent risk factor for stroke in diabetic patients ${ }^{(9,10)}$.In some studies concerning the joint prognostic effect of hypertension and type 2 diabetes on stroke risk in the general population, it is not well known whether the increasing risk of stroke comes from the effect of hypertension or type 2 diabetes alone or from the combined effect of both hypertension and type 2 diabetes $^{(11,12)}$.It is suggested that one of the risk factors for stroke in patients with T2DM is high activity of cells with histamine receptors and prostaglandin-synthesising cells. These cells suppress cell-mediated immunity to insulin and may have a role in promoting the development of insulin resistance ${ }^{(13)}$. Modifiable risk factors includes Hypertension, Cardiac diseases, Atrial fibrillation, Coronary heart disease, Left ventricular hypertrophy, Cigarette smoking, Diabetes mellitus, Asymptomatic carotid stenosis, Dyslipidemias, Total cholesterol, HDL choles- terol, LDL cholesterol, Triglycerides, Alcohol consumption, Physical inactivity, Obesity, Hematocrit level, Fibrinogen ${ }^{(14)}$. Non modifiable risk factors include age, sex, family history and race $^{(15)}$.

\section{PREVENTION}

Stroke prevention in patients with diabetes involves multi-factorial interventions. The most effective strategies include strict blood pressure control, anti platelet therapy, and lipid altering therapy. Although glucose-lowering therapy has been shown to reduce micro-vascular disease, its effect on macro vascular disease is unclear, and there are no conclusive data showing a benefit in stroke patients ${ }^{(16)}$; however, there are data showing a reduction in macro vascular disease in patients with type 1 diabetes managed with a glucose-lowering strategy ${ }^{(17) .}$

\section{TABLE 1:-}

\begin{tabular}{|l|l|}
\hline $\begin{array}{l}\text { MODIFIABLE } \\
\text { RISK FACTORS }\end{array}$ & \multicolumn{1}{|c|}{ MANAGEMENT } \\
\hline Hypertension & $\begin{array}{l}\text { Regular screening for hypertension (at } \\
\text { least every 2 years in adults) and } \\
\text { appropriate management. }\end{array}$ \\
\hline Smoking & $\begin{array}{l}\text { Strongly encourage patient and family to } \\
\text { stop smoking. Provide counselling, } \\
\text { nicotine replacement, and formal } \\
\text { programs as available. }\end{array}$ \\
\hline Diabetes & $\begin{array}{l}\text { Careful control of hypertension in both } \\
\text { type 1 and type 2 diabetics }\end{array}$ \\
\hline Carotid stenosis & $\begin{array}{l}\text { Endarterectomy may be considered } \\
\text { (21) }\end{array}$ \\
\hline Atrial fibrillation & $\begin{array}{l}\text { Antithrombotic therapy (warfarin or } \\
\text { aspirin) }\end{array}$ \\
\hline Hyperlipidemia & $\begin{array}{l}\text { Treatment with a statin } \\
\text { (23) }\end{array}$ \\
\hline Obesity & Weight reduction ${ }^{(21)}$ \\
\hline Physical inactivity & Regular exercise \\
\hline Poor diet & $\begin{array}{l}\text { A healthy diet containing at least 5 daily } \\
\text { servings of fruits and vegetables }\end{array}$ \\
\hline Alcohol abuse & $\begin{array}{l}\text { No more than 2 drinks per day for men } \\
\text { and 1 drink per day for non pregnant } \\
\text { women }{ }^{(19)}\end{array}$ \\
\hline
\end{tabular}

\section{TREATMENT}

Tissue plasminogen activator (tPA) was approved for the treatment of acute ischemic stroke in the United States in 1996 and in Canada in February 1999. The barriers to using tPA for acute ischemic stroke are dominated by 
the short time window: the drug must be administered within 3 hours of stroke onset. Patients must fulfill strict inclusion criteria because of the risk of symptomatic intracerebral haemorrhage. Another major impedement is the lack of public understanding of what the symptoms of stroke are ${ }^{(25)}$ Stroke thrombolytic therapy with intravenous alteplase may be ineffective for patients with severe ischemic stroke due to large vessel occlusion. Angiographically controlled studies using duteplase (double-chain, recombinant tissue-type plasminogen activator) found that recanalization of large vessel occlusions were uncommon after a 60-minute infusion ${ }^{(26)}$.

\section{CONCLUSION}

The mortality rate and the incidence of stroke are in concordance with the results of many studies, and they indicate that T2DM is a strong risk factor for stroke. In patients with disturbances of carbohydrate metabolism the course of stroke is worse, the period of rehabilitation is longer and the mortality rate is higher ${ }^{(27)}$ Some systematic overview shows that in patients with no history of diabetes who have an ischemic stroke, even moderately elevated glucose levels are associated with both a 3-fold higher risk of short-term mortality and an increased risk of poor functional recovery compared with lower glucose levels. This finding is supported by studies showing higher mean admission glucose level in non survivors of stroke compared with survivors ${ }^{(28)}$. Thus, this review article conclude that management of diabetes is important to reduce the risk of ischemic stroke in patients, since it plays one of the major cause of stroke.

\section{REFERENCES}

1. Harris MI, Flegal KM, Cowie CC, Eberhardt MS, Goldstein DE, Little RR, Wiedmeyer HM, Byrd-Holt DD: Prevalence of diabetes, impaired fasting glucose, and impaired glucosetolerancein U.S. Adults: the Third National Health and
Nutrition Examination Survey, 19881994. Diabetes Care 21:518-524, 1998.

2. Wolf PA, D'Agostino RB, Belanger AJ, Kannel WB. Probability of stroke: a risk profile from the Framingham study. Stroke. 1991;22: 312-318.

3. Epidemiology of Ischemic Stroke in Patients With Diabetes, BRETT $M$. KISSELA, MD1 JANE KHOURY, MS2 DAWN KLEINDORFER.

4. The Impact of History of Hypertension and Type 2 Diabetes at Baseline on the Incidence of Stroke and Stroke Mortality Gang $\mathrm{Hu}, \mathrm{PhD}$; Cinzia Sarti, PhD; Pekka Jousilahti, PhD; Markku Peltonen, PhD; Qing Qiao, PhD; Riitta Antikainen, PhD; Jaakko Tuomilehto, $\mathrm{PhD}$

5. Lehto S, Ro“nnemaa T, Pyo“ra"la" K, Laakso M. Predictors of stroke in middleaged patients with non-insulin-dependent diabetes. Stroke. 1996; 27:63-68.

6. The global burden of cerebrovascular disease Thomas Truelsen, Stephen Begg , Colin Mathers

7. Sex Differences in Stroke Epidemiology A Systematic Review Peter Appelros, MD, $\mathrm{PhD}$; Birgitta Stegmayr, $\mathrm{PhD}$; Andreas Tere'nt, MD, PhD

8. Lehto S, Ronnemaa T, Pyorala K, Laakso M. Predictors of stroke in middle-aged patients with non-insulin-dependent diabetes. Stroke. 1996; 27:63-68.

9. Davis TM, Millns H, Stratton IM, Holman RR, Turner RC. Risk factors for stroke in type 2 diabetes mellitus: United Kingdom Prospective Diabetes Study (UKPDS) 29. Arch Intern Med. 1999;159:1097-1103.

10. Iso H, Imano H, Kitamura A, Sato $S$, Naito Y, Tanigawa T, Ohira T, Yamagishi K, Iida M, Shimamoto T. Type 2 diabetes and risk of nonembolicischaemic stroke in Japanese men and women. Diabetologia. 2004;47:2137-2144.

11. Kissela BM, Khoury J, Kleindorfer D, Woo D, Schneider A, Alwell K, Miller R, 
Ewing I, Moomaw CJ, Szaflarski JP, Gebel J, Shukla R, Broderick JP. Epidemiology of ischemic stroke in patients with diabetes: the greater Cincinnati/Northern Kentucky Stroke Study. Diabetes Care. 2005;28:355-359.

12. Risk factors for stroke in type 2 diabetes mellitus NAILYA ASFANDIYAROVA, NINA KOLCHEVA, IGOR RYAZANTSEV, VLADIMIRRYAZANTSEV

14. Multiple modifiable risk factors for first ischemic stroke: a population-based epidemicological study D. I. Hadjieva, P. P. Minevab and M. I. Vukova aMedical University, Sofia, Bulgaria; and bMedical Faculty, Thracian University, StaraZagora, Bulgaria

15. Sacco RL, Benjamin EJ, Broderick JP, et al. American Heart Association Prevention Conference IV: prevention and rehabilitation of stroke: risk factors. Stroke. 1997;28:1507 \pm 1517 .

16. UK Prospective Diabetes Study (UKPDS) Group. Effect of intensive blood-glucose control with metformin on complications in overweight patients with type 2 diabetes (UKPDS 34). Lancet. 1998;352: 854-865.

17. The Diabetes Control and Complications Trial/Epidemiology of Diabetes Interventions and Complications (DCCT/EDIC) Study Research Group. Intensive diabetes treatment and cardiovascular disease in patients with type 1 diabetes. $\mathrm{N}$ Engl J Med. 2005;353:2643-2653.

18. Joint National Committee. The sixth report of the Joint National Committee on Prevention, Detection, Evaluation, and Treatment of High Blood Pressure. Arch Intern Med. 1997;157:2413 \pm 2446 .

19. Guide to Clinical Preventive Services: Report of the US Preventive Services Task Force. 2nd ed. Baltimore, Md: Williams \& Wilkins; 1996.
20. American Diabetes Association. Clinical practice recommendations 1998. Diabetes Care. 1998;21(suppl 1):S1 \pm S89.

21. Primary Prevention of Ischemic Stroke Larry B. Goldstein, MD, Chair; Robert Adams, MD; Kyra Becker, MD; Curt D. Furberg, MD; Philip B. Gorelick, MD.

22. Laupacis A, Albers G, Dalen J, et al. Antithrombotic therapy in atrial fibrillation. Chest. 1998;114(suppl):579S-589S.

23. Joint National Committee. The sixth report of the Joint National Committee on Prevention, Detection, Evaluation, and Treatment of High Blood Pressure. Arch Intern Med. 1997;157:2413 \pm 2446 .

24. Pate RR, Pratt M, Blair SN, et al. Physical activity and public health: a recommendation from the Centers for Disease Control and Prevention and the American College of Sports Medicine. JAMA. 1995;273: 402 \pm 407 .

25. Building a "brain attack" team to administer thrombolytic therapy for acute ischemic stroke Michael D. Hill,* Phillip A. Barber,* Andrew M. Demchuk,* Robert J. Sevick, $\uparrow$ Nancy J. Newcommon, *Teri Green,* Alastair M. Buchan*

26. Acute Intravenous-Intra-Arterial Revascularization Therapy for Severe Ischemic Stroke Michael D. Hill, MD; Philip A. Barber, BM; Andrew M. Demchuk, MD; Nancy J. Newcommon, MN; Andrea ColeHaskayne, RN.

27. Risk factors for stroke in type 2 diabetes mellitus NAILYA ASFANDIYAROVA, NINA KOLCHEVA, IGOR RYAZANTSEV, VLADIMIRRYAZANTSEV

28. Stress Hyperglycemia and Prognosis of Stroke in Nondiabetic and Diabetic Patients: A Systematic Overview, Sarah E. Capes, Dereck Hunt, Klas Malmberg, Parbeen Pathak and Hertzel C.Gerstein. 